\title{
RARE TIGER BEETLES (COLEOPTERA: CARABIDAE, CICINDELINAE) OF CROATIA: NEW FINDINGS AND CURRENT DISTRIBUTION
}

\section{Andreja Brigić ${ }^{*}$, Snježana Vujčić-Karlo ${ }^{2}$, Boris Lauš ${ }^{3}$ \& Toni Koren ${ }^{3}$}

\author{
${ }^{1}$ Department of Biology, Faculty of Science, University of Zagreb, Rooseveltov trg 6, \\ HR-10000 Zagreb, Croatia \\ ${ }^{2}$ National Museum Zadar, Natural History Department, Medulićeva 2, HR-23000 Zadar, Croatia \\ ${ }^{3}$ Association Hyla, Lipovac I no.7, HR-10000 Zagreb, Croatia
}

Brigić, A., Vujčić-Karlo, S., Lauš, B. \& Koren, T.: Rare tiger beetles (Coleoptera: Carabidae, Cicindelinae) of Croatia: new findings and current distribution. Nat. Croat., Vol. 29, No 2, 299-306, 2020, Zagreb.

Here we present new records of two rare tiger beetles in Croatia, their distribution and habitat selection. Cylindera trisignata trisignata (Dejean, 1822) was recorded in Croatia, for the first time in 115 years, on Mljet Island in Blace Bay. Specimens were collected on a sandy beach, $5-6 \mathrm{~m}$ from the water's edge sea coast. Cylindera arenaria viennensis (Schrank, 1781) was found in Croatia, for the first time in 67 years, in Podravina, in Kloštar Podravski. It was collected in an area previously exploited for sand mining, which was later abandoned and left to the natural succession. Both species were recorded in rare natural or semi-natural sandy habitat types that are endangered in Croatia. The survival of these and other psammophilous species depends on the suitable management and protection of sandy habitats.

Key words: Cylindera trisignata trisignata, Cylindera arenaria viennensis, new records, sandy habitats, coastal dunes, sand dunes, embryonic shifting dunes, Pannonic inland dunes

Brigić, A., Vujčić-Karlo, S., Lauš, B. \& Koren, T.: Rijetke hitre (Coleoptera: Carabidae, Cicindelinae) Hrvatske: novi nalazi i trenutna rasprostranjenost. Nat. Croat., Vol. 29, No 2, 299-306, 2020, Zagreb.

Ovdje predstavljamo nove nalaze dviju rijetkih vrsta hitri u Hrvatskoj, njihovu rasprostranjenost i opis staništa. Cylindera trisignata trisignata (Dejean, 1822) je zabilježena u Hrvatskoj, nakon 115 godina, na otoku Mljetu u zaljevu Blace. Jedinke su sakupljene na pješčanoj plaži, na udaljenosti od 5 do $6 \mathrm{~m}$ od mora. Cylindera arenaria viennensis (Schrank, 1781) pronađena je u Hrvatskoj, nakon 67 godina, u Podravini u Kloštru Podravskom. Sakupljena je na području koje se prije koristilo za vađenje pijeska i potom prepušteno prirodnoj sukcesiji. Obje vrste hitri zabilježene su na rijetkim prirodnim i poluprirodnim pješčanim stanišnim tipovima koji su ugroženi u Hrvatskoj. Opstanak ovih i drugih psamofilnih vrsta ovisi o odgovarajućem upravljanju i zaštiti tih staništa.

Ključne riječi: Cylindera trisignata trisignata, Cylindera arenaria viennensis, novi nalazi, pješčana staništa, obalne dine, pješčane dine, embrionske obalne sipine, kontinentalne panonske sipine

Tiger beetles are globally distributed, with the exception of Antarctica, Arctic (north of latitude $65^{\circ}$ ), and some isolated oceanic islands (Pearson \& Vogler, 2001). They inhabit various habitat types such as alpine meadows, desert grasslands, sandy beaches and tropical rain forests, and have been recorded at elevations of up to 3,500 $\mathrm{m}$ a.s.1. (Pearson \& Vogler, 2001). Many tiger beetles are habitat specialists and, as such, are widely used as bioindicators (PeArson \& Cassola, 1992; Rodrígues et al., 1998). Adults are often colourful, highly mobile and daytime ground foragers, while larvae live in 
the soil where they dig out narrow burrows. Both adults and larvae prey on other invertebrates (PeArson \& CAssola, 1992).

The tiger beetle fauna of Croatia, which is still poorly known, comprises 12 species with several subspecies (Brigić \& Vujčić-Karlo, 2007). However, this statement is derived mainly from older literature (e.g. SCHLOSSER-KLEKOVSKI, 1877; ŠEBišANOvić, 1888; Langhoffer, 1896, 1913; Apfelbeck, 1904; Csiki, 1946; NovaK, 1952, 1970; Müller, 1957), findings from museum collections, and a relatively small number recent findings of the authors (BRIGIĆ \& VUJČIĆ-KARLO, 2007). The aim of this study is to revise the distribution of Cylindera trisignata trisignata (Dejean, 1822) and Cylindera arenaria viennensis (Schrank, 1781) in Croatia, based on new findings and old literature data, and to provide further insight on their habitat preferences.

Specimens of C. trisignata trisignata and C. arenaria viennensis were identified according to Horn (1938), Cassola (1973), Gebert in Müller-Motzfeld (2006) and Lompe (2020). Nomenclature follows Löвl \& SMETANA (2003). Voucher specimens are deposited in the first author's collection (University of Zagreb, Faculty of Science, Department of Biology, Croatia) and in the Coleoptera collection of the Hyla Association (Zagreb).

Distribution maps were created in ArcGIS 10.2 (https://www.arcgis.com/) using new and literature records. The latter were georeferenced with the locality name and the coordinates of corresponding centroids available at the Gazetteer of Geographical Names of the Republic of Croatia (State Geodetic Administration, 2020).

\section{Cylindera trisignata trisignata}

In total, eight specimens of $C$. trisignata trisignata (4 males and 4 females; Fig. 1a) were recorded in the Mediterranean biogeographical region (EEA, 2015), in Blace Bay on Mljet Island (N 42.691165, E 17.743891). Specimens were hand collected on sandy soil on June $15^{\text {th }}, 2019$. They were found $5-6$ meters from the water's edge, with the highest activity observed 3 meters from the water (leg. B. Lauš; Fig. 1b). Blace Bay is located in the easternmost part of Mljet Island. It is almost completely isolated and separated from the open sea by a $500 \mathrm{~m}$ long and, on average, $50 \mathrm{~m}$ wide sandy beach in the centre. The morphology of this stretch of the coastline ensures a relatively low impact of tides, currents and waves. The area is covered by psammophytic vegetation that belongs to the class Cakiletea maritimae TX et PRSG 1950, with the frequently present Cakile maritima Scop., Salsola kali L. and Euphorbia peplis L., which are creating a vegetation zone $5-16 \mathrm{~m}$ distant from the sea. This zone is followed by a zone of a fragmentarily developed Echinophoro-Elymetum farcti Gehu 1988 association (AlEgro et al., 2004). The area, characterised by well-preserved embryonic shifting dunes, has been classified as a Protected Landscape area since 1965 and is included in the NATURA 2000 network (CAEN, 2020). Our findings are in accordance with previous studies stating that $C$. trisignata trisignata inhabits sandy sea beaches and saltmarshes across the Balkan Peninsula (JaskuŁA, 2007; JaskuŁA et al., 2011, 2019).

Our specimens were collected 115 years after the species was first recorded for Croatia, in Zadar (Apfelbeck, 1904; Fig 1c). This predominantly West-Mediterranean species is currently divided into five subspecies: C. t. atlantica (Barthe, 1922), C. t. corsica Rivalier, 1962, C. t. hellenica (Cassola, 1973), C. t. neustria Rivalier, 1962 and C. t. siciliensis (Horn, 1891) (Putsckov \& Matalin, 2003). The presence of C. t. siciliensis was recorded for Croatia (Müller, 1926; Depoli, 1930; Novak, 1952; Drovenik \& Peks, 1999) on the island of Rab (Lopar beach). As C. t. siciliensis occurs only in Italy (Sicily), Mo- 

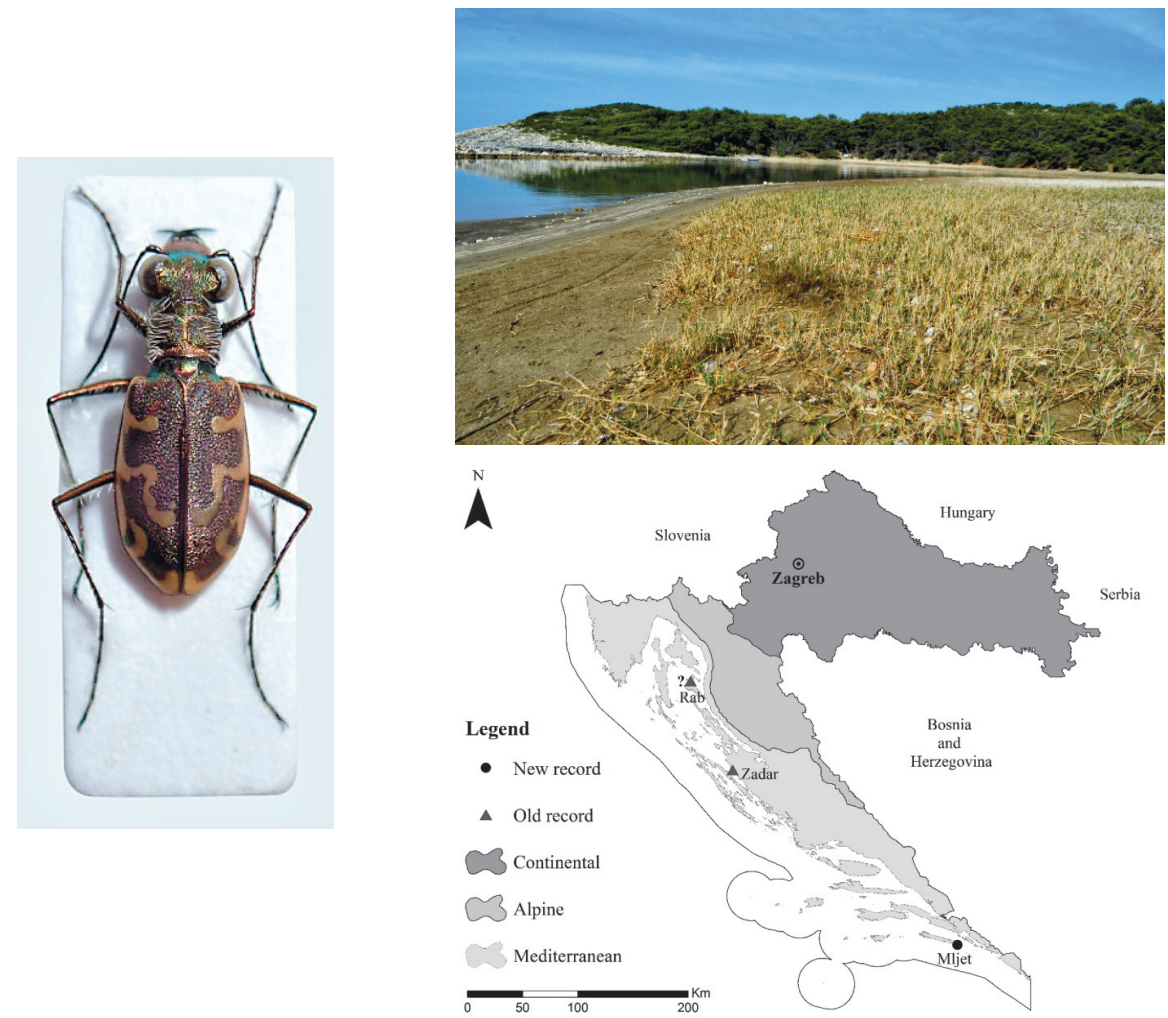

Fig. 1. a) Cylindera trisignata trisignata (Dejean, 1822), b) habitat of C. trisignata trisignata, sandy beach in Blace Bay, Mljet Island, c) distribution of C. trisignata trisignata in Croatia. Legend: ? represents doubtful findings of C. trisignata siciliensis (Horn, 1891) from 1983 and/or C. trisignata arbensis (Gridelli, 1944) from Rab Island (for details see text).

rocco, Malta, Tunisia, Lybia and Ibiza (Wiesner, 1992; Putchkov \& Matalin, 2003), it is possible that the subspecies from Rab Island was misidentified by G. B. Novak in 1893 (Müller, 1926; not by Petar Novak as stated in JAskuŁA et al., 2005), and the finding was later included in the book "Kornjaši jadranskog primorja" written by his son Petar Novak (1952). Cassola (1973) excluded C. t. siciliensis and reported C. trisignata arbensis (Gridelli, 1944) from Rab Island, but this subspecies was later synonymised with the nominal species in Putchкov \& Matalin (2003). Cylindera t. trisignata was also reported by Magistretti (1965) and Drovenik \& Peks (1999) from Rab Island. Lopar beaches were surveyed in August 2019 and May 2020 to confirm the persistence of C. t. trisignata, but without positive results (KoREN \& MARČIć, personal data). This could possibly be related to the sampling period, seasonal dynamics of the species or to the disturbance caused by tourists. Considering the current knowledge and the lack of data from Rab Island, it is difficult to conclude with certainty which subspecies was found in the area. The matter is further complicated by a drawing of the elytra from HoRn (1938), clearly different from the elytra of the nominal species. Nevertheless, taking the known distribution of $C$. trisignata subspecies into consideration (e.g. Putchkov \& Matalin, 2003; JASKUŁA, R., 2007), we regard the occurrence of the nominal species on Rab Island as most likely, but this needs further confirmation by future studies. 


\section{Cylindera arenaria viennensis}

A total of ten specimens of $C$. arenaria viennensis (4 males and 6 females; Fig. 2a) were recorded in Podravina, Kloštar Podravski (N 46.002701, E 17.170398), in the Continental biogeographical region (EEA, 2015). Specimens were hand collected on sandy soil on August 22 ${ }^{\text {nd }}, 2019$ (leg. T. Koren). More specimens were observed at the locality on the same and the following day. In this time frame, several other sandy habitats (e.g. Đurđevački pijesci, sandy banks of the Drava River) were surveyed in search of the species, but no additional specimens were found. Cylindera $a$. viennensis was recorded in an area previously used for sand extraction; the area is nowadays abandoned and under natural succession (Fig. 2b). A water-filled gravel pit, covering an area of $6 \mathrm{~m}^{2}$ and surrounded by Salix sp., is situated in the vicinity of the sand mining area. This area is characterised by a mosaic of habitats in various stages of succession, from bare sandy soils to young secondary forests. Pannonic inland dunes (h.t. 2340) and Pannonic sand steppes (h.t. 6260) are priority habitat types in the Habitats Directive, and as such are included in NATURA 2000 network (CAEN, 2020). Generally, the vegetation of the Podravina sands belongs to the Corynephoro-Festucetum vaginatae Soklić, 1943 association, dominated by psammophilous plants, such as Corynephorus canescens (L.) P. Beauv. and
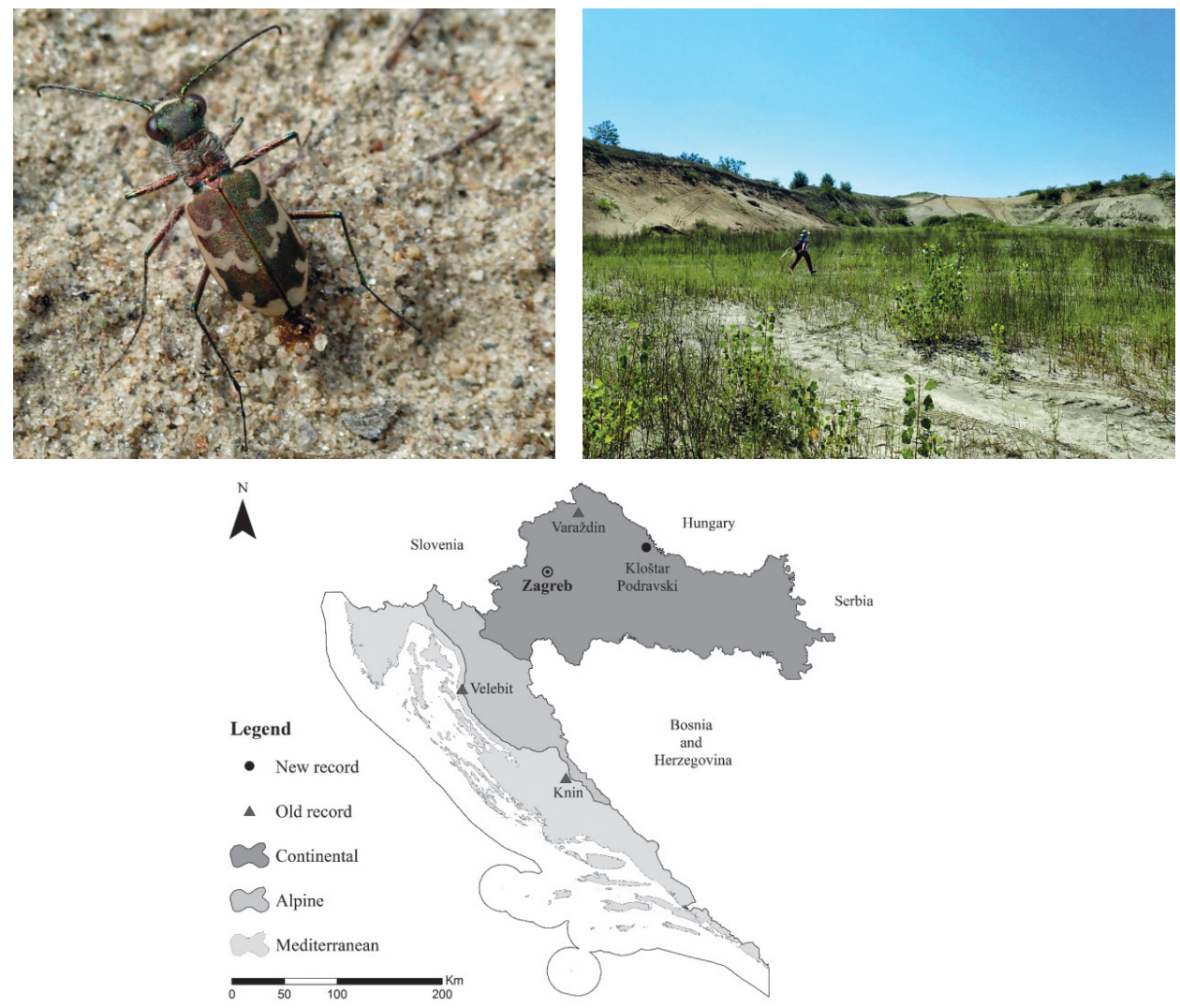

Fig. 2. a) Cylindera arenaria viennensis (Schrank, 1781), b) habitat of C. arenaria viennensis, abandoned sand extraction site in Kloštar Podravski, Podravina, c) distribution of C. arenaria viennensis in Croatia. 
Festuca vaginata Willd (SoKLIć, 1943). The sand dunes are currently endangered mainly due to vegetation succession (KRANJčEv, 2006). Weeds (e.g. Ambrosia artemisiifolia L.) and neophytes (e.g. Robinia pseudoacacia L.) are overgrowing the sand dunes, causing changes in vegetation composition and structure. Like other psammophilous species, C. arenaria viennensis inhabits the sandy banks of unregulated river reaches (JASKuŁA et al., 2011) and river banks without vegetation (LukA et al., 2009). Rare psammophilous carabid beetles have almost disappeared from the agricultural landscape in Central Europe. Because of this, gravel pits used as secondary refuges, represent valuable habitats that could ensure the persistence of these rare psammophilous species in the landscape (TraUTNER, 1996; RŨžIČKOvÁ \& HYKEL, 2019). Consequently, the maintenance of bare sandy habitat patches, which should be protected from succession, is crucial for the survival of rare psammophilous carabid beetles (RŮžIČKová \& HyKEL, 2019).

Cylindera arenaria arenaria (Füessly, 1775) is distributed predominantly in western Europe, while the subspecies C. a. viennensis (Schrank, 1781) occurs from central and eastern Europe, to western Siberia and Lake Baikal (Trautner, 1996; Putchкov \& MatALIN, 2003). Cylindera a. viennensis is a subspecies present in the Balkan Peninsula (TrAUTNER, 1996; JAskuŁa et al., 2007). Another subspecies, C. a. nudoscripta (Horn, 1915), is distributed in Azerbaijan, Armenia, Georgia, South European Territory of Russia and Turkey (Putchkov \& Matalin, 2003), thus it is not expected to occur in Croatia. Cylindera a. viennensis was first recorded for Croatia in Varaždin by F. Košćec in 1918 (Bregović, 1985). Additionally, it was also found on Velebit Mountain (Schlosser KLEKovski, 1877) and in Knin (NovaK, 1952). Interestingly, Schlosser Klekovski (1877) and Bregović (1985) reported the findings as Cicindela litteráta Sulzer, 1776, a species that was later synonymised with C. arenaria arenaria in Putchkov \& Matalin (2003). This report may suggest that the nominal subspecies occurs in Croatia. However, the samples of $C$. arenaria we examined from the Varaždin City Museum, Entomology Collection of F. Košćec (TVCM), correspond to C. arenaria viennensis, as already noted by F. Košćec in the Collection, but not included in the Bregović (1985) publication. Consequently, according to present knowledge only C. arenaria viennensis occurs in Croatia, being distributed in all three biogeographical regions: Continental, Alpine and Mediterranean (TVCM; Schlosser Klekovski, 1877; NovaK, 1952; Fig. 2c). Interestingly, C. arenaria viennensis was not recorded in recent comprehensive studies by TALLósi (2008) along the Croatian part of the Drava River.

The rediscovery of these two species confirms that the carabid beetle fauna of sandy habitats in Croatia needs further study. Sandy sea beaches and saltmarshes are speciesrich habitats for Cicindelinae in the Balkan Peninsula (JAskuŁa et al., 2011). However, these habitats are particularly threatened in the Mediterranean region of Europe including the Balkan Peninsula coastline, due to the expansion of tourism and the rapid development of tourism-related infrastructure (e.g. Arndt et al., 2005). The two new populations of $C$. trisignata trisignata and C. arenaria viennensis were located within the Natura 2000 network, in priority habitat types, reinforcing the pressure for the conservation of these areas. Sandy beaches in Croatia are rare, small, and fragmented habitats, which makes them highly endangered (Alegro et al., 2004; Stančić et al., 2008; Pikelu \& JuRAčıć, 2013). The majority of typical sandy coastal plant species in Croatia are included in the Red List (NiкоLIć \& Topić, 2005), which makes the conservation value of these habitats even higher. Additionally, rivers and streams in Croatia have been subjected to complete or partial regulation that resulted in the disappearance of many 
natural habitats (MraKovčić et al., 2006). Natural flow dynamics in floodplains is a prerequisite for C. arenaria preservation (TRAUTner, 1996). Consequently, many tiger beetles are, or could potentially be, threatened in the near future (JAsKuŁA et al., 2011), with several species already red-listed around the world (c.f. Trautner, 1996; Pearson \& Vogler, 2001; Irmler, 2010). Moreover, Trautner (1996) suggested inclusion of Cylindera arenaria in the European Habitats and Species Directive (Annex II and IV). Due to their habitat specificity, well known taxonomy, biology and ecology, and charismatic appearance, tiger beetles are globally recognised as flagship species and are used as bioindicators (Pearson \& Cassola, 1992, 2007; Pearson \& Vogler, 2001; Arndt et al., 2005). Thus, tiger beetles could be used as a leading element of insect conservation campaigns for the broad public in protected areas (e.g. Mljet National Park), with special emphasis given to the conservation of their natural and semi-natural habitats.

\section{ACKNOWLEDGEMENTS}

We thank to Andrey Matalin (Moscow State Pedagogical University) for providing us old literature and for his comments on the distribution of subspecies, to Mišel Jelić (Entomology Department, Varaždin City Museum) for providing us photos of C. arenaria from the Entomology Collection of Franjo Košćec, to Zoran Marčić (Faculty of Science) for field sampling on Rab Island and to Jelena Bujan (University of Lausanne) for linguistic help.

Received May 25, 2020

\section{REFERENCES}

Alegro, A., Biljaković, M., Bogdanović, S. \& Boršıć, I., 2004: Psammo-halophytic vegetation on the largest sand area on the Croatian coast (Island of Mljet, southern Adriatic). Biologia (Bratislava) 59, 435-445.

Apfelbeck, V., 1904: Die Käferfauna des Balkanhalbinsel, mit Berücksichtigung Klein-Asiens und der Insel Kreta. I band. R. Friedländer und Sohn Verlag, Berlin, 422 pp.

Arndt, E., Aydin, N. \& Aydin, G., 2005: Tourism impairs tiger beetle (Cicindelidae) populations - a case study in a Mediterranean beach habitat. Journal of Insect Conservation 9, 201-206.

Bregović, A., 1985: Zbirka Carabida entomološkog odjela Gradskog muzeja Varaždin. Godišnjak Gradskog muzeja Varaždin 7(7), 221-248.

Brigić, A. \& Vujčić-Karlo, S., 2009: Diversity and distribution of the tiger beetle fauna of Croatia (Coleoptera: Carabidae). In: Soldán, T., PAPÁčEK, M. \& BoHÁč, J. (eds): The International Conference SIEEC 21, České Budějovice, Czech Republic, 10.

CAEN, 2020. Bioportal - Natura 2000 ecological network. Available at: http://www.bioportal.hr/gis/. Accessed March 27 2020.

Cassola, F., 1973: Études sur les Cicindélides. VI. Contribution à la connaissance des Cicindèlides du Maroc (Coleoptera Cicindelidae). Bulletin de la Société de Sciences Naturelles et Physiques du Maroc 53(1-2), 253-268.

Csıki, E., 1946: Die Käferfauna des Karpaten-Beckens I. In: TAsnÁdi-KubacsKA, A. (ed.): Naturwissenschaftliche Monographien, IV. Budapest, 798 pp.

Depoli, G., 1930: I Coleotteri della Liburnia. Parte I: Adephaga - Palpiocornia. Fiume, Rivista Semestrale della Società di studi Fiumani, 7, 73-150.

Drovenik, B. \& Peks, H., 1999: Catalogus faunae. Carabiden der Balkanländer. Coleoptera Carabidae. Heinz Peks Schwanfeld, 103 pp.

EEA, 2015: Biogeographical regions dataset of European environment agency. Available: http://www. eea.europa.eu/data-andmaps/data/biogeographical-regions-europe-2. Accessed Nov 2015. 
Gebert, J. in Müller-Motzfeld, G., 2006: 17. Unterfamilie Cicindelinae. - In: Müller-Motzfeld, G. (Ed.): Die Käfer Mitteleuropas. Vol. 2. Adephaga 1. Carabidae (Laufkäfer). Corrected version of the 2. edition. Elsevier, München, 15-24.

Horn, W., 1938: 2000 Zeichnungen von Cicindelinen. Entomologische Beihefte aus Berlin-Dahlem, 5,1-71. 1-90 pp.

Irmler, U., 2010: Population size and mobility of Cicindela maritima Dejean, 1822 (Coleoptera: Carabidae). Angewandte Carabidologie 9, 1-6.

JAskuŁA, R., 2007: Remarks on diversity and distribution of tiger beetles (Coleoptera, Cicindelidae) of Albania. Fragmenta Faunistica 50(2), 127-138.

JAskuŁA, R., 2011: How unique is the tiger beetle fauna (Coleoptera, Cicindelidae) of the Balkan Peninsula? ZooKeys 100(100), 487-502.

JaskuŁa, R., Peśić, V. \& Pavičević, D., 2005: Remarks on distribution and diversity of the tiger beetle fauna of Montenegro (Coleoptera: Cicindelidae). Fragmenta Faunistica 4(1), 15-25.

JaskuŁa, R., PŁóciennik, M. \& Schwerk, A., 2019: From climate zone to microhabitat - environmental factors affecting the coastal distribution of tiger beetles (Coleoptera: Cicindelidae) in the south-eastern European biodiversity hotspot. PeerJ, 7,e6676.

Kranjčev, R., 2006: Pijesci u Podravini. Đurđevački pijesci, Koprivnica, Đurđevac, 104 pp.

LAnghoffer, A., 1896: Entomološki pabirci sa puta "Margite" uz neke druge entomološke podatke za Dalmaciju. Rad JAZU 9(1-6), 346-358.

LANGHoffer, A., 1913: Entomobiologička opažanja hrvatske faune. Rad JAZU 195(53), $213-225$.

Löbl, I. \& Smetana, A., 2003: Catalogue of Palaearctic Coleoptera, Vol. 1, Apollo Books, Stenstrup, 819 pp.

Lompe, A., 2020: Gattung Cylindera. Available: http://coleonet.de/coleo/texte/cylindera.htm. Accessed Mar 2020.

Luka, H., Marggi, W., Huber, C., Gonseth, Y. \& Nagel, P., 2009: Coleoptera, Carabidae: ecology, atlas. Fauna Helvetica, 24. Centre suisse de cartographie de la faune \& Schweizerische Entomologische Gesellschaft Neuchâtel. 677 pp.

Magistretti, M. 1965: Fauna d'Italia. Cicindelidae, Carabidae - Catalogo topografico. Edizione Calderini, Bologna, 512 pp.

Mrakovčić, M., Brigić, A., Buj, I., ĆAleta, M., Mustafić, P. \& Zanella, D., 2006: Crvena knjiga slatkovodnih riba Hrvatske. Ministarstvo kulture, Državni zavod za zaštitu prirode, Zagreb, 253 pp.

MüLler, G.,1926: I coleotteri della Venezia Giulia. La Editoriale Libraria, 304 pp.

MüLleR, G., 1957: Faunistična istraživanja sjeverodalmatinskih otoka Dugi otok i Kornati (1925-1927). Prirodoslovna istraživanja 28/Acta biologica 1, 187-218.

Nikolić, T. \& Topić, J. (EDS.), 2005: Crvena knjiga vaskularne flore Republike Hrvatske. Kategorije EX, RE, CR, EN i VU. Ministarstvo kulture, Državni zavod za zaštitu prirode, Zagreb, 693 pp.

NovaK, P., 1952: Kornjaši jadranskog primorja (Coleoptera). JAZU, Zagreb, 521 pp.

NovaK, P., 1970: Rezultati istraživanja kornjaša našeg otočja. Prirodoslovna istraživanja, Acta biologica 6, $5-58$.

Pearson, D. L. \& Cassola, F., 1992: World-wide species richness patterns of tiger beetles (Coleoptera: Cicindelidae): indicator taxon for biodiversity and conservation studies. Conservation Biology 6 , 376-391.

Pearson, D. L. \& Cassola, F., 2007: Are we doomed to repeat history? A model of the past using tiger beetles (Coleoptera: Cicindelidae) and conservation biology to anticipate the future. Journal of Insect Conservation 11, 47-59.

Pearson, D. L. \& Vogler, A. P., 2001: Tiger beetles: the evolution, ecology and diversity of the cicindelids. Cornell University Press. Ithaca and London, 333 pp.

Pikelj, K., \& Juračić, M., 2013: Eastern Adriatic Coast (EAC): geomorphology and coastal vulnerability of a karstic coast. Journal of coastal research 29(4), 944-957.

Putchkov, A. V. \& Matalin, A. V., 2003: Subfamily Cicindelinae Latreille, 1802. In: Löвl, L. \& Smetana, A. (eds) Catalogue of Palaearctic Coleoptera. V.1. Archeostemata - Myxophaga - Adephaga. Apollo Books, Strenstrup, 99-118.

Rodrígues, J. P., Pearson, D. L. \& Barrera, R. R., 1998: A test for adequacy of bioindicator taxa: are tiger beetles (Coleoptera: Cicindelidae) appropriate indicators for monitoring the degradation of tropical forests in Venezuela? Biological Conservation 83(1), 69-76. 
RŮŽıčKová, J. \& HүкеL, M., 2019: Habitat mosaic of gravel pit as a potential refuge for carabids: a case study from Central Europe. Community Ecology 20(3), 215-222. 177-235.

Schlosser-KLekovski, J., 1877: Fauna kornjašah Trojedne kraljevine. I, JAZU, Zagreb, 342 pp.

Soklıć, I., 1943: Biljni sviet Podravskih piesaka. Šumarski list 67, 3-34.

Stančić, Z., Brigić, A., Liber, Z., Rusak, G., Franjić, J. \& ŠKvorc, Z., 2008: Adriatic coastal plant taxa and communities of Croatia and their threat status. Acta Botanica Gallica 155(2), 179-199.

State Geodetic Administration, 2020: Gazetteer of geographical names of the Republic of Croatia, available at http://rgi.dgu.hr/home/. Accessed March 27 $7^{\text {th }}, 2020$.

ŠEbišAnović, G., 1888: Proljetno pojavljivanje koleoptera oko Varaždina god. 1888. Glasnik hrvatskog naravoslavnog družtva 3, 333-335.

TALlósI, B., 2008: Population-level baseline surveying and preparative investigations for the monitoring of carabid beetles (Coleoptera, Carabidae) in areas along the Drava river and Baranja (Croatia). In: Purger, J. J. (ed.), Biodiversity studies along the Drava River. University of Pécs Pécs., 165-220.

Trautner, J., 1996: Historische und aktuelle Bestandssituation des Sandlaufkäfers Cicindela arenaria Fuesslin, 1775 in Deutschland (Col., Cicindelidae). Entomologische Nachrichte und Berichte 40, 83-88.

Wiesner, J., 1992: Verzeichnis der Sandlaufkäfer der Welt. Checklist of the tiger beetles of the world. Verlag Erna Bauer, Keltern, 364 pp. 